Tarih Kültür ve Sanat Araştırmaları Dergisi

Revue des Recherches en Histoire Culture et Art

مجلة البحوث التاريخية و الثقافية والفنية
Vol. 7, No. 2, June 2018

Copyright (C) Karabuk University

http://kutaksam.karabuk.edu.tr

\title{
DOI: 10.7596/taksad.v7i2.1601
}

Citation: Klimova, T., Slinkova, O., Bogomazova, I., Vishnevskaya, E., \& Yakovenko, O. (2018). Positioning of Russia in the World Ranking Competitiveness of Travel and Tourism. Journal of History Culture and Art Research, 7(2), 699-707. doi:http://dx.doi.org/10.7596/taksad.v7i2.1601

\section{Positioning of Russia in the World Ranking Competitiveness of Travel and Tourism}

\author{
Tatyana B. Klimova ${ }^{1}$, Olga K. Slinkova², Irina V. Bogomazova ${ }^{3}$, \\ Ekaterina V. Vishnevskaya ${ }^{4}$, Oksana V. Yakovenko $^{5}$
}

\begin{abstract}
This article analyzes positions of Russia in world tourist space on the basis of the tourism and travel competitiveness rating provided by the World Economic Forum. At the heart of rating lies The Travel and Tourism Competitiveness Index $(\mathrm{TTCl})$ calculated on the basis of fourteen indicators grouped in four subindexes. On the basis of estimates of the indicators creating the index both the positive and negative influencing factors are allocated for a position of Russia in rating and The Travel and Tourism Competitiveness Index. It is noted that despite ambiguity of the estimates provided by the World Economic Forum, only complex assessment of the Russian tourism tendencies will allow defining new trends in its development and new mechanisms of increase in competitiveness of Russia in global tourist space.
\end{abstract}

Keywords: Tourism, Tourist space, Rating, Tourism and travel competitiveness index, Subindexes.

\footnotetext{
${ }^{1}$ Belgorod State University 308015, Belgorod, Pobeda Street, 85, Russia. E-mail: TKlimova@bsu.edu.ru

2 Belgorod State University 308015, Belgorod, Pobeda Street, 85, Russia.

${ }^{3}$ Belgorod State University 308015, Belgorod, Pobeda Street, 85, Russia.

${ }^{4}$ Belgorod State University 308015, Belgorod, Pobeda Street, 85, Russia.

${ }^{5}$ Belgorod State University 308015, Belgorod, Pobeda Street, 85, Russia.
} 


\section{Introduction}

Tourism as a system concept has space structure. The tourist space reflects the nature of tourist activity and is characterized by heterogeneity and dynamism of the development [1]. Having essential differences in the level of tourism development, the countries and regions of the world are actively integrated into world tourist space, creating, thus, the new problem field for the researches giving a basis for evaluating competitiveness of the tourism industry, creation of ratings, determinations of efficiency of tourist activity and management decisions development.

Ratings reflect results of tourism development and are drawn up on the basis of set of criteria. One of the significant world rankings is assessment of the World Economic Forum which experts calculate The Travel and Tourism Competitiveness Index. The rating of the countries according to The Travel and Tourism Competitiveness Index is published since 2007. Since 2009 the rating is represented every two years. The latest data of rating were published in February, 2017 [2].

\section{Method}

This research analyzes the position of Russia in world tourist space on the basis of the tourism and travel competitiveness rating provided by the World Economic Forum. Ranging of the countries is carried out on fourteen indicators which are grouped in four subindexes forming the final travel and tourism competitiveness index [3].

The first environment subindex integrates such indicators as: business environment, environmental protection and safety, health and hygiene, human resources and labor market, development of information and communication technologies. The second subindex, "Policy in the field of Tourism", forms proceeding from factors of priority of the tourism industry in the country, the international openness of the country, price competition and a condition of ecology in the country. The infrastructure subindex characterizes a condition of the infrastructure necessary for tourism development and integrates three indicators: development of air-transport infrastructure, land and port infrastructure, condition of tourist service infrastructure. The fourth subindex integrates natural and cultural resources of the country. In turn, each hotel indicator aggregates more detailed estimates in rating.

The final travel and tourism competitiveness index allows performing ranging of the countries, to carry out their positioning in global tourist space, to track changes of positions of this or that country in rating for a certain period. Studying of separate subindexes gives the chance of more constructive assessment of each parameter, determination of negative tendencies and a trajectory of further development of the industry.

\section{Results}

136 countries participated in the last research of the World Economic Forum provided in 2017 in rating [4]. In table 1 results of rating on the total index of competitiveness of tourism and travel are provided. On the basis of the received values, 20 ranks of competitiveness with value of the index from the highest (5.4 points) to low are allocated (3.4 points). The countries' outsiders with a position lower than 3.4 points were not considered in creation of rating [3]. 
Table 1. Ranging of the countries according to The Travel and Tourism Competitiveness Index (made according to the data provided to the WEF in 2017)

\begin{tabular}{|c|c|c|}
\hline & Country & Index \\
\hline 1 & Spain & 5.4 \\
\hline 2 & France, Germany, Japan & 5.3 \\
\hline 3 & Great Britain & 5.2 \\
\hline 4 & United States, Australia & 5.1 \\
\hline 5 & Italy, Canada & 5 \\
\hline 6 & Switzerland, SAR Hong Kong, Austria, Singapore & 4.9 \\
\hline 7 & Portugal, China, New Zealand & 4.7 \\
\hline 8 & Netherlands, Norway, Korea, Sweden & 4.6 \\
\hline 9 & Belgium, Mexico, Ireland, Greece, Spain, Malaysia, Brazil, Luxembourg, UAE, Taiwan, China & 4.5 \\
\hline 10 & Denmark, Croatia, Finland, Thailand, Panama & \\
\hline 11 & Malta & 4.3 \\
\hline 12 & Estonia, Costa Rica, Czech Republic, India, Slovenia, Indonesia, Russian Federation & 4.2 \\
\hline 13 & Turkey, Bulgaria, Poland, Qatar, Chile, Hungary, Argentina & 4.1 \\
\hline 14 & Peru, Cyprus, South Africa, Latvia & 4 \\
\hline 15 & Mauritius, Lithuania, Ecuador, Barbados, Slovakia, Bahrain & 3.9 \\
\hline 16 & Israel, Columbia, Saudi Arabia, Sri Lanka, Morocco, Oman, Vietnam, Romania & 3.8 \\
\hline 17 & Jamaica, Georgia, Azerbaijan, Montenegro, Trinidad and Tobago & 3.7 \\
\hline 18 & $\begin{array}{l}\text { Egypt, Jordan, Dominican Republic, Uruguay, Bhutan, Philippines, Kenya, Kazakhstan, } \\
\text { Namibia, Cabe Verde }\end{array}$ & 3.6 \\
\hline 19 & Armenia, Botswana, Guatemala, Tunisia & 3.5 \\
\hline 20 & Tanzania, Nicaragua, Iran, Laos, Serbia, Lebanon, Rwanda, Albania & 3.4 \\
\hline
\end{tabular}

The leader among the tourist countries of the world is Spain which has the maximum travel and tourism competitiveness index (5.4). France, Germany and Japan take the following positions and have an index 5.3 indicator. They are followed by Great Britain (5.2), the USA and Australia (5.1). Closing the group of the countries with the index 5.0 are Italy and Canada [4]. 
The Russian Federation takes the 43rd position in the general rating and enters into group of the countries with the index 4.2 together with the Czech Republic, Estonia, Indonesia, Slovenia, India, slightly advancing Turkey and Bulgaria.

In fig. 1 dynamics of positions of Russia in the rating of competitiveness (The Travel \& Tourism Competitiveness Index), since 2007 is provided. Let's note that the position of Russia for the last period increased from the 63rd place following the results of a research of the World Economic Forum of 2013 up to the 43 rd position in 2017.

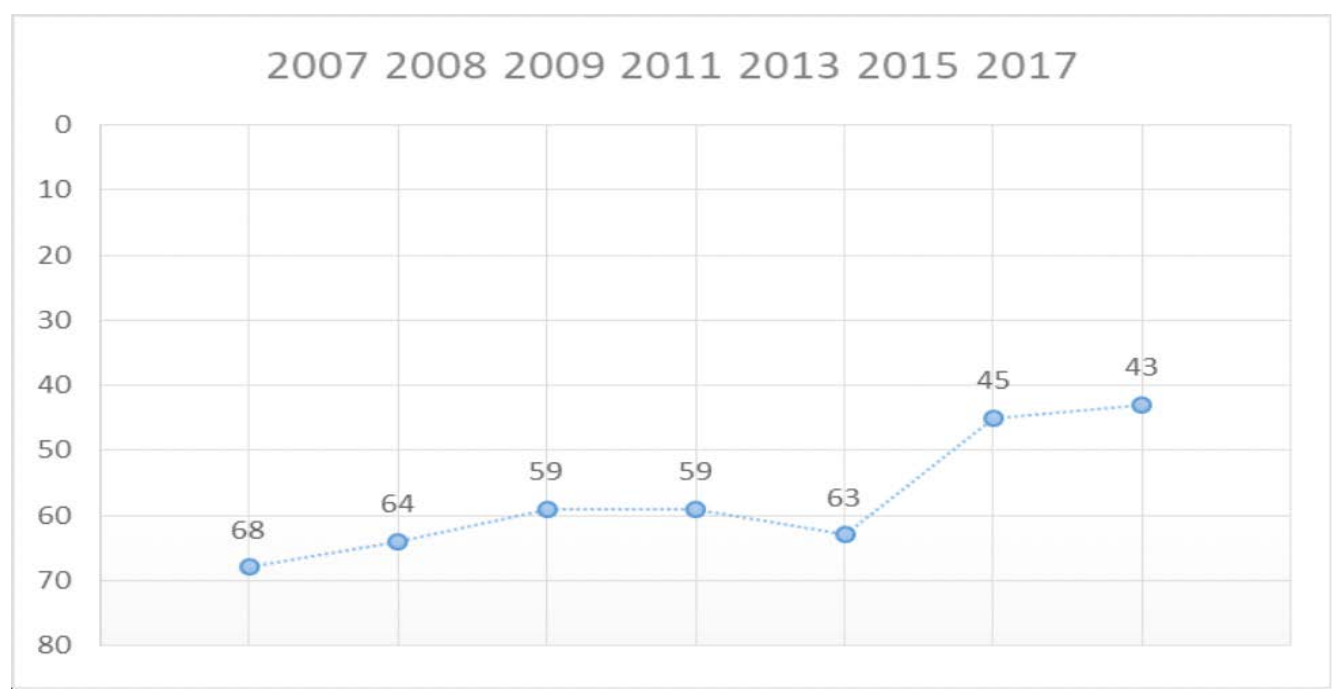

Fig. 1. Dynamics of Russian positions in the tourism and travel competitiveness rating

By the World Economic Forum the tourism share in GDP of the country makes $1.5 \%$ (17855.8 $\mathrm{mln}$. US dollars), a share of employed in tourism - 1.4\% of total number occupied (973503 jobs). The international tourist arrivals in the Russian Federation make 31346486 persons. The international receipts from tourism are $8465 \mathrm{mln}$. US dollars [4].

Let's consider changes in rating regarding the Russian Federation since 2007 and what factors exerted impact on total value of the index and, respectively, a position of the Russian Federation (Table 2).

Table 2. Change of Russian position in the rating of tourism and travel competitiveness (according to the data provided to the WEF during the period between 2007-2017)

\begin{tabular}{|c|c|c|c|c|c|c|c|c|c|c|c|c|c|c|}
\hline & \multicolumn{2}{|c|}{$\begin{array}{c}2007 \\
(124 \\
\text { countries) }\end{array}$} & \multicolumn{2}{|c|}{$\begin{array}{c}2008 \\
(130 \\
\text { countries) }\end{array}$} & \multicolumn{2}{|c|}{$\begin{array}{c}2009 \\
(133 \\
\text { countries) }\end{array}$} & \multicolumn{2}{|c|}{$\begin{array}{c}2011 \\
(139 \\
\text { countries) }\end{array}$} & \multicolumn{2}{|c|}{$\begin{array}{c}2013 \\
(140 \\
\text { countries) }\end{array}$} & \multicolumn{2}{|c|}{$\begin{array}{c}2015 \\
(141 \\
\text { countries) }\end{array}$} & \multicolumn{2}{|c|}{$\begin{array}{c}2017 \\
(136 \\
\text { countries) }\end{array}$} \\
\hline & $\begin{array}{c}\text { rati } \\
\text { ng }\end{array}$ & $\begin{array}{l}\text { ind } \\
\text { ex }\end{array}$ & $\begin{array}{c}\text { rati } \\
\text { ng }\end{array}$ & $\begin{array}{l}\text { ind } \\
\text { ex }\end{array}$ & $\begin{array}{c}\text { rati } \\
\text { ng }\end{array}$ & $\begin{array}{l}\text { ind } \\
\text { ex }\end{array}$ & $\begin{array}{c}\text { rati } \\
\text { ng }\end{array}$ & $\begin{array}{l}\text { ind } \\
\text { ex }\end{array}$ & $\begin{array}{c}\text { rati } \\
\text { ng }\end{array}$ & $\begin{array}{l}\text { ind } \\
\text { ex }\end{array}$ & $\begin{array}{l}\text { rati } \\
\text { ng }\end{array}$ & $\begin{array}{l}\text { ind } \\
\text { ex }\end{array}$ & $\begin{array}{c}\text { rati } \\
\text { ng }\end{array}$ & $\begin{array}{l}\text { ind } \\
\text { ex }\end{array}$ \\
\hline General rating & 68 & 4.0 & 64 & 4.0 & 59 & 4.1 & 59 & 4.2 & 63 & 4,2 & 45 & 4.08 & 42 & 4,2 \\
\hline $\begin{array}{l}\text { Business } \\
\text { environment }\end{array}$ & 49 & 3.8 & 65 & 3.6 & 61 & 3.7 & 53 & 4.1 & 46 & 4.2 & 109 & 3.98 & 105 & 4.1 \\
\hline
\end{tabular}




\begin{tabular}{|c|c|c|c|c|c|c|c|c|c|c|c|c|c|c|}
\hline $\begin{array}{l}\text { Protection and } \\
\text { safety }\end{array}$ & 99 & 3.7 & 127 & 3.2 & 129 & 3.5 & 113 & 4 & 113 & 3.9 & 126 & 3.95 & 109 & 4.3 \\
\hline $\begin{array}{l}\text { Health and } \\
\text { hygiene }\end{array}$ & 31 & 5.7 & 9 & 6.7 & 10 & 6.7 & 11 & 6.6 & 14 & 6.4 & 6 & 6.69 & 5 & 6.7 \\
\hline $\begin{array}{l}\text { Human } \\
\text { resources and } \\
\text { labor market }\end{array}$ & 70 & 5 & 72 & 4.9 & 88 & 4.8 & 78 & 4.8 & 92 & 4.6 & 38 & 4.83 & 46 & 4.8 \\
\hline $\begin{array}{l}\text { Development of } \\
\text { ICT }\end{array}$ & 104 & 4.3 & 111 & 4.3 & 123 & 4.1 & 136 & 3.6 & 138 & 3.7 & 46 & 4.83 & 49 & 5 \\
\hline Tourism priority & 99 & 3.1 & 80 & 4 & 74 & 4.2 & 102 & 4 & 111 & 3.6 & 90 & 4.33 & 95 & 4.2 \\
\hline $\begin{array}{l}\text { International } \\
\text { openness }\end{array}$ & & & & & & & & & & & 99 & 2.48 & 115 & 2.2 \\
\hline $\begin{array}{l}\text { Competitiveness } \\
\text { of the prices }\end{array}$ & 39 & 4.8 & 112 & 4 & 108 & 4.1 & 75 & 4.5 & 72 & 4.5 & 41 & 4.99 & 11 & 5.8 \\
\hline $\begin{array}{l}\text { Ecological } \\
\text { sustainability }\end{array}$ & 113 & 3 & 117 & 3.8 & 114 & 3.9 & 98 & 4.2 & 134 & 3.5 & 106 & 3.7 & 71 & 4.1 \\
\hline $\begin{array}{l}\text { Air-transport } \\
\text { infrastructure }\end{array}$ & 21 & 4.2 & 33 & 4.1 & 30 & 4.4 & 30 & 4.3 & 33 & 4.3 & 22 & 4.43 & 22 & 4.5 \\
\hline $\begin{array}{l}\text { Land and port } \\
\text { infrastructures }\end{array}$ & 65 & 3.5 & 83 & 3.3 & 81 & 3.2 & 95 & 3.1 & 93 & 3.1 & 92 & 3.09 & 78 & 3 \\
\hline $\begin{array}{l}\text { Tourist's } \\
\text { infrastructure }\end{array}$ & 58 & 3.2 & 66 & 3.3 & 60 & 3.5 & 45 & 4.6 & 40 & 4.9 & 54 & 5.65 & 55 & 4.5 \\
\hline $\begin{array}{l}\text { Natural } \\
\text { resources }\end{array}$ & 41 & 4.7 & 22 & 4.6 & 23 & 4.6 & 27 & 4.4 & 37 & 4.33 & 34 & 3.77 & 39 & 3.8 \\
\hline $\begin{array}{l}\text { Cultural } \\
\text { resources and } \\
\text { business trips }\end{array}$ & 49 & & 34 & 3.6 & 30 & 3.9 & 35 & 3.7 & 39 & 3.5 & 21 & 3.32 & 25 & 3.2 \\
\hline
\end{tabular}

\section{Discussion}

As it was already noted that the first subindex combines such indicators as a business environment, environmental protection and safety, health and hygiene, human resources and labor market, development of information and communication technologies. The condition of a business environment is characterized by efficiency of the legal base in the country, opportunities for business, including a profit tax rate, the preferential taxation. On this indicator positive dynamics, since 2009 was noted. Following the results of a research of 2015, there was a considerable decrease in positions to the 46 th to the 109th. Despite minor 
change of the index, according to experts of the World Economic Forum the condition of a business environment in our country considerably worsened. As far as such estimates are justified, a question debatable. Nevertheless, political differences with the European community, policy of sanctions isolated the country from world investments, large-scale projects are suspended; certainly, experts of the WEF defined opportunities for business development as very low or impracticable. According to the latest data, provided in 2017, Russia takes the 105th place (4.1 points) on this indicator that it is insignificant above a previous period. The most favorable business environment by the last estimates is in Hong Kong which is in the lead on this indicator in rating with the index 6.2 points follows it Singapore (6.1 points) and Switzerland (6.0 points).

Indicator "Environmental protection and safety" assumes protection of vital space, safety, reliability, lack of the military conflicts in the country. According to the European experts, Russia traditionally takes positions lower than 100 though following the results of the last period they improved a little. So, in 2017 the measure value made 4,3 and this 109th place in rating that above a previous period on 17 positions. Unfortunately, in the opinion of the world community Russia continues to remain the unsafe country.

The indicator "Health and hygiene" (6.7 points) is defined proceeding from availability and density of hospitals, drugstores, their availability and also a sanitary state in the country, qualities of drinking water and so forth. Since 2007 positions on this index grew by 26 points according to all available data from the Russian Federation enters the five of the leading countries, conceding only to Germany (6.9 points), Lithuania (6.8 points), Austria (6.7 points), and Belgium (6.7 points).

On an indicator "Human resources" Russia takes the 46th place in rating according to the data provided in 2017. This indicator characterizes qualification of labor power and labor market. At the same time, on qualification of labor power Russia is in the 62nd place among 136 countries which took part in rating in 2017. Positions of Russia on criterion "human resources" decreased a little. So, following the results of a research of 2015 Russia held the 38th place in rating. Level of personnel training is one of the major factors at determination of the industry competitiveness. Now considerable attention at the level of the state is paid to this question.

Regarding development of information and communication technologies, by this criterion Russia holds the 49th place in rating (5 points), having a little lowered positions relatively of the data provided in 2015 , but considerably having risen rather previous periods. It should be noted that information space actively develops. Stable growth of online channels allows speaking about large-scale transition to the online interface. Tourists give preference to booking of different services in network more and more. For example, if to speak about sale of electronic train tickets, then the share of the bookings performed remotely reached a point of 44.7\%, almost every second purchased ticket - electronic [5]. In 2017 impressive change of percent of online bookings is recorded. Active response to requirements of the market, expansion and improvement of function for convenient online bookings will contribute to the further development of information and communication technologies in the country.

Such factor as priority of the tourism industry in the country, assumes support of the industry from the state, availability of the different projects aimed at the tourism development infrastructure, availability of state programs in tourism development, the public expenditures on tourism development and their share in the state budget, marketing effectiveness and branding for involvement of tourists and also timeliness of providing monthly or quarter data on tourism. Let's note that since 2011 in the country "Development of internal and entrance tourism in the Russian Federation" is implemented federal target (2011-2018), regional programs for tourism development are developed [3]. Now the draft of the concept of the federal target program providing implementation of actions for creation of tourist clusters in the Russian Federation since 2019 is discussed. Despite considerable efforts of the state in this direction, the world 
community considers these measures not sufficient for tourism development in the country therefore Russia takes only the 95th place in rating from 136 countries and has a measure value 4.2 points. The maximum positions on this criterion were reached in 2009; Russia took the 74th place [4].

On an indicator "The international openness" Russia takes the index equals the 2.2 and 115 place in rating [4]. Requirements to the visa are the dominating factor, exerting impact on this indicator. On visa restrictions Russia takes the 120 th position in rating (10 points). Despite certain steps towards mitigation of visa formalities the image of Russia as the closed country remains. Mitigation of a visa regime, certainly affects growth of a tourist flow to the country. So, visa abolition with South Korea promoted increase tourist flow of tourists in the first year for $70 \%$ [2].

The most open country according to the World Economic Forum is Singapore (5.2 points), it is followed by Australia (4.8 points), Chile (4.7 points), Colombia (4.6 points), and New Zealand (4.5 points). Japan closes the ten of the most open countries, having at the same time rather tough visa policy. Let's note that Tokyo is also the safest city according to The Telegraph [6].

Russian Federation occupies high position in the rating of competitiveness of travel and tourism on an indicator of price competition. By this criterion Russia takes the 11th position in rating and has an indicator of 5.8 points. According to the data provided in 2013 Russia took the 72nd position from 140 countries, according to 2015 - 41 line in rating. Certainly, depreciation of the ruble in 2014 played a role, and Russia was rather "cheap" country for many foreign tourists who used this factor.

In the rating of competitiveness, infrastructure factors are important. On set of infrastructure indicators Russia takes the 45th place in rating (the infrastructure subindex 4.1 points). Really, the Russian airlines began to fly more abroad, opened newer directions, internal air traffic develops. As for land and port infrastructure, here, according to experts, it is very poorly developed, and on quality of roads Russia takes 121 places in the rating of 136 countries, i.e. infrastructure of land transport significantly lags behind other countries of the world.

The number of rooms of means of placement (the 83rd place) and quality of tourist infrastructure are in the lower lines of rating (the 116th place in rating). As for the number of rooms, offers on step-by-step introduction in the territory of the Russian Federation of obligatory classification of hotels and other means of placement are developed now.

Thus, according to researches, the provided World Economic Forum, it is possible to allocate both the positive and negative influencing factors for a position of Russia in rating and The Travel and Tourism Competitiveness Index. So, among positive factors we will note high positions on indicator "health and hygiene", competitiveness of the prices, the developed air-transport infrastructure, and availability of natural and cultural resources in the country. The following belongs to factors of a negative impact: international openness, environmental protection and safety, business environment, priority of tourism, development of land and port infrastructure.

Domestic researchers pay considerable attention to studying of the factors influencing tourism development, detail subindexes more deeply, develop the estimates and techniques of competitiveness of the countries in the field of tourism, different ratings are drawn up [7-13].

It should be noted that for assessment of the situation with tourism development within the country the national tourist rating is fundamental. At the heart of national rating the official data provided by Federal State Statistics Service, the Ministry of Culture, the Ministry of Internal Affairs of the Russian Federation. For creation of national rating the following indicators are used [14]: 
- Number of places in collective means of placement which characterizes the level of development of hotel business and infrastructure in the region;

- The share of employed in the field of tourism and hospitality from the general population of the region, shows priority of the industry in region economy;

- Income of collective means of placement, volume of paid tourist services to the population, turnover of catering establishments;

- Tthe number of citizens of the Russian Federation and the foreigners placed in collective means of placement, number of spending the night in collective means of placement characterizes popularity of the region at citizens of the Russian Federation and at foreigners;

- Tourist uniqueness which is defined by quantity of the sights entered in the unified state register of objects of cultural heritage, including objects of UNESCO;

- The volume of ecological payments for negative impact on the environment, characterizes ecological "health" of the region;

- The number of the committed crimes on 1000 inhabitants of the region (a criminogenic situation);

- Interest in the region on the Internet as to the vacation spot, is defined proceeding from amount of requests in search engines about rest in the region and promotions of tourist capacity of the region in information space (the number of publications and messages in media).

\section{Conclusion}

Apparently from set of criteria of national tourist rating, a part of indicators correlate with indicators of the world ranking. At the same time, in our opinion, primary sources of information for drawing up national rating are more transparent and proved. Despite ambiguity of the estimates provided by the World Economic Forum it is impossible to abstract from them. When developing concepts and industry development programs all analytical data, including expert evaluations of the world community should be accumulated. Only complex assessment of the Russian tourism tendencies will allow defining new trends in its development and new mechanisms of increase in competitiveness of Russia in global tourist space.

\section{References}

Bogomazova I. V.; Yakovenko O. V. \& Stenyushkina S. G. (2016). Tendencies and prospects of development of the tourism industry in the world, Russian Federation and the Belgorod region. ljaber, 14, 9 (2016), 56695682

Bogomazova, I. V. \& Yakovenko, O. V. (2016). Market of the international tourism: state and tendencies of development [An electronic resource]. Network scientific and practical magazine Nauchny Rezultat. It is gray. Technologies of business and service. No. 2., pp. 7-14. URL: http://researchresult.ru/journal/business/annotation/643 (reference date 18.11.2017). 
Bukher, S. (2016). Competitiveness of Russia in the global tourist market [An electronic resource]. Region Economy, 12, 240-250. URL: https://cyberleninka.ru/article/n/konkurentosposobnost-rossii-na-globalnomturisticheskom-rynke (reference date 21.11.2017).

Cherevichko, T. V. (2015). Tourism as system: research methodology. Scientific and methodical online magazine Concept, 7 (July), 6-10. URL: http://e-koncept.ru/2015/15224.htm (reference date 18.12.2017).

Information project "I Go by Train!" [Electronic resource]. Access mode: http://www.trn-news.ru/travel-bytrain (reference date 22.12.2017).

Klimova, T. B. (2017). Tourism in estimates of the World Economic Forum. Industry of tourism and service: popularity, image, investments: the collection of articles on materials of the International scientific and practical conference. NIU "BELGU", on November 23, 2017. Belgorod: ID Belgorod. pp. 75-81.

Klimova, T. B.; Vishnevskaya E. V. \& Anopriyeva E. V. (2017). Structure and dynamics of tourist flows: tendencies and the defining factors [An electronic resource]. The Network scientific magazine Service $V$ Rossii I Za Rubezhom, 11, 5(75), 6-18. Access mode: https://elibrary.ru/item.asp? id=29764786 (reference date 10.12.2017).

Locust, M. A. (2017). Competitiveness of the tourist sphere of the countries of the world as basis of sustainable development: methodology and results of assessment. In M. A. Sarancha. Modern problems of service and tourism, 11(1), 18-24.

Morozov, M. A. (2012). Model of assessment of competitiveness of tourist destinations. Messenger of the Russian state trade and economic university, (70), 100-108.

National tourist rating of 2017 (2017). [Electronic resource]. URL: http://russia-rating.ru/info/13018.html (reference date 20.12.2017).

Rating of the cities of the world. [Electronic resource]. URL: http://news.turizm.ru/uk/54474/ (reference date 20.11.2017).

Russia suggested India to ask the procedure of receiving tourist visas. URL: http://www.trnnews.ru/digest/65888. (Reference date 20.11.2017).

TOP 100 of the most popular cities of the world. [Electronic resource]. URL: http://www.trnnews.ru/analytics/65858 (reference date 21.11. 2017).

Travel and tourism of Competitiveness Report 2017. [Electronic resource]. URL: http://reports.weforum.org/travel-and-tourism-competitiveness-report-2017/ranking/ (reference date 20.11.2017). 